\title{
OS IMPACTOS DA GLOBALIZAÇÃO NOS DIREITOS POLÍTICOS: EXPERIÊNCIAS E TENDÊNCIAS
}

\author{
THE GLOBALIZATION IMPACTS ON POLITICAL RIGHTS: \\ EXPERIENCES AND TRENDS
}

\author{
André Gustavo de Almeida Geraldes ${ }^{1}$ \\ Nayara Maria Silvério da Costa Dallefi ${ }^{2}$
}

\begin{abstract}
Resumo: O presente estudo discorre sobre a evolução histórica dos direitos políticos, a partir do conceito da palavra "política", na Grécia Antiga, até a concretização normativa por intermédio do Direito Internacional dos Direitos Humanos, após a Segunda Guerra Mundial. Nesse contexto, examina-se a globalização como um fenômeno que impacta significativamente no exercício dos direitos políticos. Investiga-se, a partir de textos bibliográficos, principalmente aqueles produzidos por Hannah Arendt, a importância da dimensão política da condição humana, e a importância da integração dos povos, por meio da globalização pautada na proteção dos direitos humanos, haja vista que as diferentes formas de isolamento (econômico, político e cultural) enfraquecem a capacidade de participação da sociedade civil, podendo ser considerado a base da tirania. $O$ presente artigo segue a metodologia histórica bibliográfica, a partir do método dedutivo.
\end{abstract}

Palavras-chave: Globalização. Direitos Humanos. Participação Política.

Abstract: The present study deals with the historical evolution of political rights, from the concept of the word "politics" in Ancient Greece, to normative fulfillment through International Human Rights Law, after the Second World War. In this context, globalization is examined as a phenomenon that has a significant impact on the exercise of political rights. The importance of the political dimension of the human condition and the importance of the integration of peoples, through globalization based on the protection of human rights, are investigated from bibliographical texts, especially those produced by Hannah Arendt. Forms of isolation (economic, political and cultural) weaken civil society's capacity for participation and can be considered the basis of tyranny.

Keywords: Globalization. Human Rights. Political Participation.

\footnotetext{
${ }^{1}$ Doutor em Direito pela The University of New South Wales (UNSW) e Mestre em Direito pela Pontifícia Universidade Católica de São Paulo (PUC/SP). É professor da Faculdade de Direito da PUC-SP. Advogado.

${ }^{2}$ Doutoranda em Direito na Pontifícia Universidade Católica de São Paulo - PUC; Mestre em Direito, pelo Programa de Estudo Pós Graduado em Direito, do Centro Universitário Eurípedes de Marília - UNIVEM (2016); Pós-graduada na área do Direito pela Universidade Estadual de Londrina-UEL (2012); Bacharel em Direito pelas Faculdades Integradas Antônio Eufrásio de Toledo, em Presidente Prudente-SP (2009). Atualmente é advogada militante e professora universitária na Universidade do Oeste Paulista - UNOESTE em Presidente Prudente-SP. Tem experiência na área do Direito, com ênfase em Direito Civil, Direito Previdenciário e Processual Civil. Coordenadora da Comissão da Assistência Judiciária de Presidente Prudente-SP ( $3^{\circ}$ mandato), também na cidade de Presidente Prudente-SP. Membra do grupo de pesquisa CODIP do Centro Universitário Eurípedes de Marília - UNIVEM. E-mail: naydallefi@ hotmail.com / nayaradallefi@adv.oabsp.org.br
} 
Sumário: INTRODUÇÃO - 1. O FENÔMENO DA GLOBALIZAÇÃO - 2. CONSIDERAÇÕES SOBBRE A DIMENSÃO POLÍTICA DA CONDIÇÃO HUMANA 3. DIREITOS HUMANOS POLÍTICOS - 4. IMPACTOS POSITIVOS DA GLOBALIZAÇÃO NOS DIREITOS POLÍTICOS - 5. O AVANÇO DA GLOBALIZAÇÃO E A ATUAL CRISE DA REPRESENTAÇÃO POLÍTICA - 6. CONCLUSÃO - REFERÊNCIAS BIBLIOGRÁFICAS.

\section{INTRODUÇÃO}

O fenômeno da globalização provoca impactos significativos no exercício dos chamados Direitos Políticos. É fato que vemos na atualidade inúmeros casos de afronta direta aos direitos humanos, incluindo os direitos políticos, mas também não podemos deixar de reconhecer os avanços em termos de positivações de direitos fundamentais, como jamais vistos na história da humanidade antes das duas guerras mundiais.

Com o final das grandes guerras em 1945, o mundo iniciou um processo de globalização, pautado no sistema capitalista, que é visto como impossível de ser revertido a qualquer sistema anterior da história da humanidade.

As atrocidades durante as duas grandes guerras trouxeram uma preocupação mundial em busca de um bom governo, em prol da coletividade, pautado na democracia, que foram construindo-se aos poucos, com ênfase nos países ocidentais, e muito é necessário avançar.

A Declaração Universal dos Direitos Humanos de 1948 representa um grande marco, principalmente com o Pactos Internacionais de 1966, seja o que trata dos Direitos Civis e Políticos, seja o que trata dos Direitos Econômicos, Sociais e Culturais, concretizando o preconizado na primeira e segunda geração - ou dimensão - de direitos humanos, ou seja, a liberdade e igualdade - diga-se, para nosso trabalho: liberdade política e igualdade voltada aos direitos sociais.

Com esta preocupação, partindo de uma pesquisa histórica bibliográfica, e valendose do método dedutivo, o presente artigo examina os impactos do fenômeno da globalização nos direitos políticos, sob um enfoque de suas experiências e tendências. Para tanto, busca-se estruturar o presente trabalho trazendo primeiramente as considerações sobre o conceito de globalização, para posteriormente abordar os conceitos de política, ciência política e direitos políticos, para em seguida tratar dos impactos positivos da globalização no exercício dos 
direitos políticos e, por fim investigar a relação entre globalização e a atual crise da representação política.

\section{O FENÔMENO DA GLOBALIZAÇÃO}

A necessidade de integração entre os povos é uma característica inerente às sociedades humanas. Desde as primeiras atividades comerciais, por intermédio do escambo, até as trocas de conhecimento, frequentemente facilitadas pelos movimentos de expansão territorial, nota-se um fenômeno de gradual aproximação entre os agrupamentos humanos.

Desde o período das grandes descobertas do século XV e XVI, no entanto, verificase uma significativa intensificação desse fenômeno marcado pela aceleração dos fluxos internacionais de pessoas, bens e informações.

Esta interligação demonstra que "a terra se tornou mundo, de que o globo não é mais apenas uma figura astronômica, e sim o território no qual todos encontram-se relacionados e atrelados (...) a Terra mundializou-se (...)".3

Com efeito, esse fenômeno de integração dos povos engendra uma quebra de paradigmas em relação ao ser, sentir, agir, pensar e fabular, trazendo novos conceitos, e rompendo dogmas, levando o ser humano a formular outras conclusões, por exemplo, de que "a Terra não é mais o centro do universo, conforme Copérnico"4. A partir deste cenário, a globalização começou a ser tratada a partir de conceitos metafóricos, conforme assevera IANNI (2001, p.15-16):

O problema da globalização, em suas implicações empíricas e metodológicas, ou históricas e teóricas, pode ser colocado de modo inovador, propriamente heurístico, se aceitamos refletir sobre algumas metáforas produzidas precisamente pela reflexão e imaginação desafiadas pela globalização. Na época da globalização, o mundo começou a ser taquigrafado como "aldeia global", "fábrica global", "terrapátria", "nave espacial”, "nova Babel” e outras expressões. São metáforas razoavelmente originais, suscitando significados e implicações. Povoam textos científicos, filosóficos e artísticos. [...] Suscitam ângulos diversos de análise, priorizando aspectos sociais, econômicos, políticos, geográficos, históricos, geopolíticos, demográficos, culturais, religiosos, linguísticos, etc. Mas é possível reconhecer que vários desses aspectos são contemplados por metáforas como

\footnotetext{
${ }^{3}$ IANNI, Octavio. 1926 - Teorias da Globalização/ Octavio Ianni. 9a Ed. - Rio de Janeiro: Civilização Brasileira, 2001, p.13.

${ }^{4}$ Dai nascem a surpresa, o encantamento e o susto. Daí a impressão de que se romperam modos de ser, sentir, agir, pensar e fabular. Algo parecido com as drásticas rupturas epistemológicas representadas pela descoberta de que a Terra não é mais o centro do universo conforme Copérnico, de que o homem não é mais filho de Deus segundo Darwin, de que o indivíduo é um labirinto povoado de inconsciente de acordo com Freud (IANNI, 2001, p.14).
} 
"aldeia global”, “fábrica global”, "cidade global”, "nave espacial”, "nova babel", entre outros.

A partir desse cenário de busca por integração entre os povos, a globalização pode vista como um processo contínuo, alavancando principalmente ao longo do século $\mathrm{XX}$, em virtude de relevantes acontecimentos históricos, dentre outros, as Guerras Mundiais, Guerra Fria, queda do Muro de Berlin, podendo valer da conclusão de IANNI (2008), que "a globalização não é um fato acabado, mas um processo em marcha”.

Diferentemente de outros movimentos sociais e correntes filosóficas e políticas registradas ao longo da história da humanidade, a globalização não tem um ponto exato para seu surgimento. Há antecedentes, porém, que contribuíram para a sua construção, conforme ensina LONGCHAMP (2000, p. 125-126):

Uma ideologia no reverso da história: Contrariamente às grandes correntes da modernidade, a globalização não tem um teórico. Por enquanto. O capitalismo nasceu no espírito frio de Adam Smith. O marxismo sabe de quem depende. $\mathrm{O}$ freudismo idem. O existencialismo é o fruto de amores incestuosos do cristão trágico e do ateísmo, de Kierkegaard e de Sartre. A globalização não tem pai. Mas tem antecedentes.

Há que se pontuar que as reinvindicações sociais face ao sistema capitalista também proporcionou este alavancar da globalização, tal como exemplo, a Constituição do México, em 1917, que trouxe cláusulas de cunho econômico e social, servindo de exemplo para outras constituições ocidentais "além das clássicas liberdades e garantias individuais; mantinha o capitalismo, mas traçava os primeiros contornos do Estado Social de Direito", assim como no mesmo sentido a Constituição da Alemanha da 1919.

Outro importante fato que demonstra o capitalismo mundial foi o crash e da Bolsa de Valores de Nova York, em 1929, demonstrando o impacto global na economia e no mercado internacional ${ }^{6}$.

Não poderia deixar de mencionar sobre a Declaração Universal de Direitos Humanos, em 1948, em que influenciou com grande ênfase os países Ocidentais, na busca por direitos iguais, e posteriormente os dois Pactos Internacionais de 1966, vale dizer, o Pacto dos Direitos Civis e Políticos, e o pacto dos Direitos Econômicos, Sociais e Culturais, que

\footnotetext{
${ }^{5}$ SAYEG, Ricardo; BALERA, Wagner. Capitalismo Humanista - Filosofia Humanista e Direito Econômico. $1^{\text {a }}$ ed., p.53. Petrópolis: KBR Editora Digital, 2011,

${ }^{6}$ SAYEG, Ricardo; BALERA, Wagner. Capitalismo Humanista - Filosofia Humanista e Direito Econômico. $1^{\text {a }}$ ed., p.55. Petrópolis: KBR Editora Digital, 2011,
} 
colaboraram para uma maior integração dos povos, em termos de um piso mínimo de dignidade humana.

No entanto, o maior instrumento para a consolidação do fenômeno da globalização é a expansão da rede mundial de computadores (internet), que proporciona uma conexão instantânea entre as diversas partes do orbe terrestre, trazendo inúmeros benefícios econômicos, comerciais, sociais e culturais. Infelizmente, a internet pode também distanciar as pessoas do contato físico, e em muitos casos, pode ainda ser utilizada para excluir os seres humanos e desrespeitar a dignidade humana, por exemplo, com a proliferação de manifestações racistas, xenofóbicas, homofóbicas e misóginas. É fato notório o crescente uso da internet para a proliferação das chamadas fake news, que causam danos irreversíveis à opinião pública, inclusive podendo macular o exercício livre e consciente dos direitos políticos.

Podemos considerar que o objetivo da globalização é a criação de uma economia capitalista, mas com igualdade para todos, devendo ser nossa tarefa e mais, nossa responsabilidade ${ }^{7}$, evitando ambiguidades em seu aspecto econômico, cultural e social, na busca de uma globalização sem exclusão, minimizando os riscos da padronização e acima de tudo, respeitando o ser humano. Neste diapasão, expõe brilhantemente LONGCHAMP (2000, p.147-155):

O homem é um criador de riquezas nato. Este é seu dever, desde o Gênesis. A economia, a empresa, os serviços, são os lugares desta criação. Assim como eles habitam e operam nesta ótica, permanecem na ordem das coisas e na lógica de sua função social. O processo de globalização é portador de potencialidades reais. Ele pode contribuir para a unidade do mundo na medida em que assegura uma globalização sem marginalização. [...] A globalização implica um risco evidente de padronização. Este é o horror do pensamento único, a perda de valores espirituais e morais, e sua fusão numa modernidade banalizadora. A cultura "McWorld", como a nomeia Benjamin Barber, ele próprio norte-americano e antigo conselheiro de Bill Clinton, "ameaça a autonomia da sociedade civil e os domínios da cultura e do espírito. McWorld tem seus porta-bandeiras favoritos: McDonald's, Disney e Coca Cola. Graças a liberdade de trocas, ele divulga no mundo um gosto americano de pacotilha". [...] Nosso tempo é um século humilhado. Ouso esperar que ele não será uma geração perdida. Tenho um sonho: a globalização sairá dos trilhos da produtividade, das fusões, da concentrações, para se preocupar com o bem-estar de todos dentro do respeito de cada um...Eu o disse: tenho um sonho. Não duvido um segundo que a realidade mercantil não deixará quase espaço para estas divagações. Mas é ali, talvez, que se introduz uma riqueza que não está à venda e que pode até se oferecer em superabundância sem risco de nos empobrecer: a esperança. Ninguém

${ }^{7}$ LONGCHAMP, Albert. Globalização: o novo nome do desenvolvimento? In Globalização e fé. Bauru: EDUSC, 2000. Páginas 130. 
impedirá os seres humanos em sua busca de ser mais-ser, de mais humanidade.

Conclui-se, que diante os antecedentes da globalização, ela impacta todos os setores da sociedade, independentemente da localidade, sendo que a economia de mercado caminha a seu lado, de modo que os riscos são muitos, mas não podem ser óbice de uma política igualitária, que ao menos possa proporcionar oportunidades àqueles que ficam marginalizados do sistema capitalista, para que ai sim, todo o globo possa estar unido em prol da proteção da dignidade da pessoa humana.

Não se pretende esgotar a análise do fenômeno da globalização nas páginas do presente trabalho, entretanto, faz-se importante abordar um pouco sobre sua parte conceitual, com o fim de demonstrar que este fenômeno se consolida com a liberalização dos fluxos comerciais, principalmente a partir da segunda metade do século XX.

Desta feita, é necessária uma visão da globalização com relação aos Direitos Humanos, principalmente o Direito Humano Político, como se analisará no presente trabalho, como forma de não só garantir o princípio da dignidade da pessoa humana, mas um direito humano político, como uma condição humana.

\section{CONSIDERAÇÕES SOBRE A DIMENSÃo POLÍTICA DA CONDIÇÃo HUMANA}

Para falar sobre política, necessário se faz primeiramente buscar seu conceito a partir dos estudos de Aristóteles, sobretudo a sua obra "Ética a Nicômaco", que relaciona a política como a ciência da felicidade humana - subdividido em duas partes: a primeira é a ética e a segunda é a política propriamente dita9 .

Com efeito, a felicidade humana deveria ter relação direita ao modo de vida de qualquer pessoa a partir deste ponto, criar as leis e a estrutura da sociedade local, de modo a trazer um bem comum e a felicidades de todos que ali habitam.

Esta relação da felicidade com a política visa um bem-estar social, que de certa forma, mesmo parecendo uma utopia, seria a partir deste ponto de partida para a criação de

\footnotetext{
${ }^{8}$ Aristóteles nasceu em Stágiros (posteriormente Stágira, atualmente Strava), na Calcídice, território macedônio, em 384 a.C., e morreu em Cálcis (atual Evripo), na Eubéia, e, 322. Era filho de Nicômacos, da condraria dos asclepíadas, médico e amigo de Amintas II, rei da Macedônia (ARISTÓTELES. Política. Tradução da Gama Kury. Brasília: Editora Universidade de Brasília, 1985, pg.10).

${ }^{9}$ Idem, pg. 13.
} 
um governo para assegurar o modo de viver em sociedade. Sob esta visão, a política é considerada uma ciência prática, senão vejamos:

A ciência prática por excelência é a "política", isto é, a ciência do bem-estar e da felicidade dos homens como um todo; ela é a prática no sentido mais amplo da palavra, pois estuda não somente o que é felicidade (assunto da ética), mas também a maneira de obtê-la, (o assunto política); ao mesmo tempo ela é prática no sentido mais estrito, pois leva à demonstração de que a felicidade não é resultado das ações, mas é em si mesma uma certa maneira de agir. ${ }^{10}$

Contudo, referida questão da busca pela felicidade e constituição de um governo, recaí na questão do ideal de felicidade, que é subjetivo para cada indivíduo, o que realmente lhe traz felicidade, e diante deste fato, também surge uma outra questão, a de conceituar justiça, tanto de forma individual quanto coletiva, pois cada pessoa tem uma forma de pensamento e anseios diferentes ${ }^{11}$.

Sem esgotar o tema da justiça, visto que não é objeto de nosso trabalho em si, é que para concretizar a política, deve-se haver justiça, sendo necessário que as leis atendam os anseios da coletividade, dentro dos preceitos do princípio da isonomia e de acordo ao estabelecido nas Constituição de determinada sociedade.

A ciência política tem com a característica do povo de determinado território, que segundo seus anseios e forma de agir em busca da felicidade, busca a melhor forma de governo, senão vejamos:

Um povo capaz por natureza de produzir uma estirpe excelente nas qualidades necessárias ao comando político é um povo feito para a monarquia; um povo cujos componentes se sujeitam, como homens livres, a

\footnotetext{
${ }^{10}$ Idem, pg. 14.

${ }^{11}$ Surgem também dificuldades quando se quer saber quem deve deter o poder soberano na cidade, pois ele pode ser exercido pelas massas, pelos ricos, ou pelos homens bons, ou por um só homem melhor que todos os outros, ou por um tirano, mas todas estas alternativas parecem envolver consequências desagradáveis. Por exemplo, não seria injusto que os pobres se prevalecessem de sua superioridade numérica para dividir entre si mesmo os bens dos ricos? Certamente não, diriam alguns, pois o poder supremo assim quis, e legitimamente. (...) mas o princípio de que a maioria é necessariamente mais apta a exercer o poder soberano do que uns poucos homens excelentes pode justificar-se, e embora talvez levante alguma dificuldades ele é provavelmente verdadeiro. É realmente possível que os integrantes da maioria, apesar de não serem isoladamente homens bons, possam ser melhores quando reunidos, não individualmente, mas coletivamente, do que os poucos individualmente bons da mesma forma que os banquetes públicos, para os quais muitos contribuem, são melhores que os oferecidos a expensas de um só homem; realmente, pode-se argumentar que onde há muitos homens, cada um tem uma certa porção de bondade e prudência, e que quando eles se reúnem, da mesma maneira que a multidão se transforma num só homem com muitos pés e muitas mãos e muitos sentidos, podem assumir também uma só personalidade quanto às faculdade morais e intelectuais. Há, porém, outra dificuldade, relacionada com a anterior; acha-se absurdo que as pessoas inferiores devam ter poder decisórios em assuntos mais importantes que os atribuídos às mais respeitáveis; a tomada de contas e a escolha dos altos funcionários são realmente matérias muito importantes, mas em algumas constituições, elas são atribuídas ao povo (ARISTÓTELES, 1985, p. 103-105).
} 
ser governados por homens cujas qualidades os credenciam para o comando político é feito para a aristocracia, e o povo feito para o governo constitucional é aquele entre cujos componentes existe uma maioria combativa, construída de homens capazes de mandar e obedecer alternadamente sob uma lei que distribui as funções de governo entre os homens de posses de acordo com seus méritos. Quando acontece, então, que há uma família inteira (ou mesmo algum cidadão) de tal forma proeminente sobre as outras qualidades que superam as de todas as outras, então é justo que este cidadão seja um rei, pois como foi dito antes isto se coaduna não apenas com o direito geralmente adquirido pelo fundadores de governo aristocráticos e oligárquicos, e também pelos criadores de governos democráticos (todos baseiam suas pretensões na superioridade, embora não na mesma superioridade) (ARISTÓTELES, 1985, p.123).

Para BONAVIDES (2000, p. 25), sobre o assunto assevera que "de Aristóteles a Kant não se faz atenta discriminação entre os conceitos de ciência política. E quase se pode dizer que a separação conceitual pertence à idade moderna".

Isto porque, a ciência política busca estudar os fatos e ideias tanto no aspecto doutrinário como prático, unindo o passado com o presente, para a construção de um futuro de uma determinada sociedade. Para tanto, é necessário o enlace do estudo da ciência política com a filosofia, para toda essa construção.

Cumpre observar que a ciência política tem relação com diversas áreas de estudo, como: Direito Constitucional ${ }^{12}$; Economia ${ }^{13}$; História $^{14}$ e Sociologia ${ }^{15}$, o que traz uma difícil tarefa trazer um conceito exato acerca do tema, mas não deixando qualquer dúvida da necessidade de seu estudo quando tratar dos direitos do cidadão em relação ao Estado.

${ }^{12}$ São apertadíssimos os laços que prendem a Ciência Política ao Direito Constitucional. Entre os publicistas célebres na França, no século XX, autores há que se preocuparam menos com o aspecto jurídico da Ciência Política do que propriamente com suas raízes na filosofia e nos estudos sociais. Naquele país, a Ciência Política, antes de chegar à maioridade como disciplina autônoma, esteve quase toda contida no Direito, mormente no Direito Constitucional. A despeito do cisma operado, este ainda é o ramo da Ciência Jurídica cujo influxo mais pesa sobre a Ciência Política (BONAVIDES, 2000, p. 52).

${ }^{13}$ Sem conhecimento dos aspectos econômicos em que se baseia a estrutura social, dificilmente se poderia chegar à compreensão dos fenômenos políticos e das instituições pelas quais uma sociedade se governa. Reputase pacífico o entendimento de cientistas políticos como Burdeau, que não precisam de ser marxistas, para reconhecer no fato econômico "o fundamental de politização da sociedade". Admitida essa tese, perceber-se-á sem dificuldades a importância capital que tem para a Ciência Política toda a matéria de que se ocupa a Economia Política, ela mesma, em outras espécies, considerada uma das ciências políticas (BONAVIDES, 2000, p. 54).

${ }^{14}$ Ciência Política e a História - Quando se toma a História como acumulação crítica de fatos e experiências vividas, fácil se torna perceber a importância de seu estudo para a Ciência Política e a contribuição essencial que o historiador poderá oferecer nesse domínio. Se o filósofo, o economista, o sociólogo e o jurista quiseram, em outras épocas, monopolizar a Ciência Política ou imprimir-lhe uma diretriz que traduzisse exclusividade de perspectiva, também o historiador não foi insensível a essa orientação, querendo igualmente apropriar-se daquela disciplina, para reduzi-la a mera investigação acerca da origem e do desdobramento dos sistemas, das ideias e das doutrinas políticas, conhecidas e praticadas pelo gênero humano no decurso de tantos séculos (BONAVIDES, 2000, p. 56).

${ }^{15}$ A Ciência Política possui âmbito mais largo que a Sociologia Política. Posto que conservem inumeráveis pontos de contato ou partilhem ambas um terreno comum e vasto, verdade è que se não confundem as duas disciplinas (BONAVIDES, 2000, p. 60). 
Sobre os direitos do cidadão perante o Estado a que está relacionado, desde a Roma Antiga, tem resquícios, mas não na mesma intensidade que nos dias atuais, principalmente após a Segunda Guerra Mundial, que proporcionou a concretização, em âmbito normativo, dos chamados direitos políticos.

Mesmo para uma parcela restrita da população, na Grécia Antiga já havia aqueles que almejavam a concretização pela ordem política, conforme já analisado, assim como também na Roma Antiga, até seu apogeu. Entretanto, referido cenário fica praticamente nulo durante a Idade Média, quando o saber se concentrou nas mãos da Igreja e do Soberano.

Contudo, novamente é aflorado com ênfase durante o Iluminismo, sendo que dentre vários fatores que corroboram para este retorno, mesmo que de forma restrita, temos a nova forma de empregar o termo Estado por intermédio da obra "O Príncipe" de Maquiavel. Para BONAVIDES (2000, p. 83) "há pensadores que intentam caracterizar o Estado segundo posição predominantemente filosófica; outros realçam o lado jurídico e, por último, não faltam aqueles que levam mais em conta a formulação sociológica de seu conceito".

Outro ponto a ser considerado, com o advento do Iluminismo está adstrito à teoria da separação dos poderes, formulada na obra de Montesquieu, influenciando uma nova forma de Estado, em busca de liberdade dos poderes monárquicos. Muito embora, para BONAVIDES (2000, p. 172), sobre o assunto, também pontua:

Locke, menos afamado que Montesquieu, é quase tão moderno quanto este, no tocante à separação de poderes. Assinala o pensador inglês a distinção entre os três poderes - executivo, legislativo e judiciário - e reporta-se também a um quarto poder: a prerrogativa. Ao fazê-lo, seu pensamento é mais autenticamente vinculado à Constituição inglesa do que o do autor de Do Espírito das Leis.

Conclui-se que o conceito de política é amplo, não se esgotando em uma só vertente de estudo, ou em um único doutrinador, podendo ter relação com diversas áreas de estudo, fazendo com que a ciência política, seja de suma importância, para o estudo do Estado e da Sociedade, tanto na forma de governo, como para economia e até mesmo para a própria filosofia, visando de forma precípua a busca do bem comum, seja de forma individual como coletiva, assim como na busca da concretização do justo para uma determinada sociedade.

\section{DIREITOS HUMANOS POLÍTICOS}


A partir do conceito de política e da ciência política, de forma sucinta, necessário abordar outra problemática, que a doutrina entende por direito político. Neste diapasão, os direitos políticos "são prerrogativas e os deveres inerentes à cidadania, no sentido de outorgar à população o direito de participar direta ou indiretamente do Estado, isto é, da escolha das decisões tomadas pelos órgãos governamentais"16.

Importante se faz mencionar que não existe uma data com exatidão para o nascimento dos Direitos Humanos. De um lado, há aqueles que entendem que seu início se dá na Antiguidade, sendo concomitante com o Direito, e com ele podendo se confundir. De outro, há pensadores que apontam o seu surgimento no mundo Ocidental, juntamente com a Idade Moderna, entre os séculos XVI e XVIII ${ }^{17}$.

Cumpre lembrar que o fim da Segunda Guerra Mundial e, portanto, das atrocidades nazistas $^{18}$, propiciam o surgimento de um amplo movimento de positivação dos direitos fundamentais e a supremacia da Constituição, principalmente em relação aos direitos políticos, conforme será tratado no próximo item, como também surge a chamada judicialização política, conforme ensina MARINONI (2013, p.73):

O judicial review, antes de afirmar, ao menos explicitamente, o poder de o judiciário controlar a atividade do legislativo, fundou-se na supremacia da Constituição sobre as leis, na ideia de que a lei que nega a Constituição é nula, e, mais enfaticamente, na constatação de que o judiciário é o interprete final da Constituição e, assim, por lhe caber pronunciar o sentido da lei, também é dele o poder de dizer se a lei é contrária à Carta Magna.

Sem contar o princípio da dignidade da pessoa humana, analisado como ponto central, com o escopo de enaltecer os valores éticos e morais, elevando os direitos

16 GAMO, Raphaela. O que são Direitos Políticos e sua relação com os Direitos Humanos?. [S.l., s.n], [entre 1995 e 2018]. Disponível em: http://www.apersonalidadejuridica.com.br/2016/04/o-que-sao-direitos-politicos-esua-relacao-com-os-direitos-humanos.html. Acesso em: 06 jun. 2018.

17 Quando nascem os Direitos Humanos? Eles já se encontram na tradição antiga e medieval ou são uma novidade absoluta na Modernidade? Segundo uma opinião difusa, eles existiram desde os tempos imemoriais, como mostra Antígona, a "heroína do direito natural", protagonista da tragédia homônima de Sófocles, que desobedeceu as leis da cidade para obedecer às leis não-escritas (ágraphta nómina). Os críticos dessa concepção afirmam que assim se confunde o Direito com os Direitos Humanos. O Direito (díkaion em grego, jus em latim) existe a partir do momento em que os grupos humanos constituem cidades-Estados, ou seja, desde o início das primeiras civilizações urbanas (civitates); enquanto que os Direitos Humanos seriam tipicamente modernos e ocidentais, ou seja, nascem num determinado período histórico e numa determinada civilização: a europeia dos séculos XVI/XVII (TOSI, 2009, p. 47).

${ }^{18}$ Veja-se o Estado de Direito alemão (Rechtsstaat), por exemplo, que fora concebidos em termos meramente formais, ou seja, previa um sistema no qual o poder público era exercido pelos órgãos competentes de acordo com os procedimentos previamente estabelecidos na lei. Entretanto, todo esse ideal foi desacreditado pelo regime nazista, que acabou por instituir com base na legalidade lógica do "tudo é possível", levando pessoas serem tratadas como supérfluas e descartáveis, contrariando os valores consagrados da Justiça e do Direito. (...) O modelo democrático alemão, entra, desta maneira, em colapso, causando sofrimento a toda a humanidade. Uma inimaginável mistura de totalitarismo, nazismo, genocídio e imperialismo causou sofrimento às pessoas, desrespeitando-se qualquer ideia de direitos fundamentais (BARBOSA, 2014, p.79). 
fundamentais no patamar constitucional, buscando respeitar todas as pessoas (BARBOSA, 2014, p.82).

Prosseguindo, os direitos humanos busca em proporção global ter um caráter indivisível, para o fim de efetivar os direitos econômicos, culturais, sociais, civis e políticos ${ }^{19}$.

Assim, as prerrogativas do cidadão, conquistadas ao longo da história da humanidade, principalmente após a Segunda Guerra Mundial, em países Ocidentais, exceto naqueles que mantiveram regime ditatorial, vão de encontro com o princípio da dignidade da pessoa humana, com avanço substancial em relação aos direitos políticos.

Referidos direitos - direitos políticos - inerentes ao cidadão, tem como escopo a oportunidade de participar da escolha de seus representantes, em prol da ordem jurídica, podendo ser divididos tanto da forma ativa como passiva, necessitando para tanto a capacidade política ${ }^{20}$.

O direito político, mais que um direito fundamental, é um direito humano conquistado no percorrer da história da humanidade, como uma das formas de concretização do princípio da dignidade da pessoa humana.

O direito humano deve ser analisado em uma ótica supranacional, a partir da Declaração Universal dos Direitos Humanos, enquanto os direitos fundamentais, na esfera nacional, pautados nos direitos humanos e adaptando-os em consonância com as normas internas, respeitando o princípio do relativismo cultural.

No Brasil, muitos direitos, dentre eles até mesmo os direitos políticos, foram sufocados diante o período da Ditadura Militar, vigente no Brasil de 1964 a 1985, por intermédio do Ato Institucional $\mathrm{n}^{\circ} 1$, quando determinou que as eleições presidenciais por

\footnotetext{
${ }^{19}$ Este sistema global de proteção dos direitos humanos é integrado, além da Declaração Universal de Direitos Humanos, pelo Pacto Internacional de Direito Civis e Políticos, pelo pacto internacional dos Direitos Econômicos, Sociais e Culturais e ainda por outras Convenções Internacionais. Paralelamente ao Sistema global, têm-se os sistemas regionais de proteção dos direitos humanos com aparatos jurídicos próprios. O sistema interamericano tem uma Convenção Americana de Direitos Humanos, de 1969, seu principal instrumento, a qual previu a Comissão Interamericana de Direitos Humanos e a Corte Interamericana (BARBOSA, 2014, p.89).

${ }^{20}$ Ativos: consiste no direito-dever (obrigação do voto) do cidadão escolher livremente seus candidatos, participar de plebiscitos e referendos, emitir opiniões, etc.

Passivos: se configuram no direito de o candidato poder receber o voto de seus concidadãos. Para que essa prerrogativa possa existir, ele deve preencher todos os requisitos inexoráveis ao jus bonorum, demonstrando possuir as condições necessárias de elegibilidade.

Capacidade política ativa: começa com o alistamento eleitoral e termina com o voto.

Capacidade política passiva: acontece com o cumprimento das condições de elegibilidade, possibilitando ao cidadão ser aceito a um cargo público.

Direito-dever: direito de votar em quem desejar e dever obrigatório de votar, passível de sanção de multa pelo não cumprimento ou não justificação.

GAMO, Raphaela. O que são Direitos Políticos e sua relação com os Direitos Humanos?. [S.1., s.n], [entre 1995 e 2018]. Disponível em: http://www.apersonalidadejuridica.com.br/2016/04/o-que-sao-direitos-politicos-e-suarelacao-com-os-direitos-humanos.html. Acesso em: 06 jun. 2018.
} 
maioria absoluta do Congresso Nacional, como também pela Emenda de 1969, quando as eleições passaram a ser indiretas, dentre outras alterações, como o voto vinculado, impossibilitando o eleitor votar em candidatos de partidos distintos, para deputado Estadual e Federal. Os Atos Institucionais restringiram de forma substancial os direitos políticos, como:

[...] suspensão do direito de votar e de ser votado nas eleições sindicais, a proibição de atividade ou manifestação sobre assunto de natureza política, e também a aplicação das chamadas "medidas de segurança", quais sejam: liberdade vigiada, proibição de frequentar determinados lugares e domicílio determinado, sempre que os comandantes militares entendessem que as medidas eram necessárias para a ordem política e social. Tal previsão foi agravada pelo $\mathrm{AI} \mathrm{n}^{\circ} 5$, no qual havia previsão de que o ato que suspendesse os direitos políticos poderia fixar restrições ou proibições relativamente ao exercício de quaisquer outros direitos públicos ou privados. [...] Por meio do AI $n^{\circ}$ 5, os Comandantes Militares atribuíram ao Presidente da República a possibilidade de decretar o recesso do Congresso Nacional, das Assembleias Legislativas e das Câmaras dos Vereadores. [...] Portanto, o regime ditatorial suprimiu os mais basilares direitos de cidadania. A superação da ditadura militar para o regime democrático foi marcada pela participação política de grande parte da população brasileira, em especial no movimento das diretasjá. ${ }^{21}$

É condição sine qua non evidenciar, segundo MORAES (2012, p. 239), os direitos políticos são "o conjunto de regras que disciplina as formas de atuação da soberania popular, conforme preleciona o art. 14 da Constituição Federal. São direitos públicos subjetivos que investem o indivíduo no status activae civitatis".

$\mathrm{O}$ artigo acima fundamenta o mesmo doutrinador, os seguintes direitos políticos: direito de sufrágio, alistabilidade, elegibilidade, iniciativa popular de lei, ação popular e organização e participação o de partidos políticos (MORAES, 2012, p. 240).

Sendo assim, o direito político proporcionou, não só no Brasil, mas também que todos os demais países que seguem os preceitos da Declaração Universal dos Direitos Humanos, uma maior valorização dos princípios democráticos, proporcionando maior liberdade, igualdade e solidariedade.

Um direito humano político com intuito de proporcionar maior liberdade, tem relação às conquistas tais como liberdade de expressão - mas é claro que cada um é responsável pelos seus atos e dizeres - liberdade em relação a seus direitos políticos - seja ativo como passivo - liberdade de agir e reivindicar seus direitos humanos, principalmente de

\footnotetext{
${ }^{21}$ MACEDO, Fausto. Cidadania aprisionada: O Direito eleitoral na ditadura. [S.l., s.n], [entre 1995 e 2018]. Disponível em: http://politica.estadao.com.br/blogs/fausto-macedo/cidadania-aprisionada-o-direito-eleitoral-naditadura/. Acesso em: 06 jun. 2018.
} 
cunho político. Contudo, não podemos confundir nesse cenário a liberdade com o individualismo e livre-arbítrio. Melhor nesses conceitos, ÁVILA (1997, p. 18) ensina:

\begin{abstract}
Entretanto o individualismo confunde liberdade e livre-arbítrio. Liberdade é a propriedade de um se realizar em plenitude a sua natureza. Um homem é tanto mais livre quanto melhor pode realizar a natureza humana, integral e harmonicamente. Livre-arbítrio é uma faculdade do ser livre, pela qual pode agir ou não agir; agir desta ou daquela maneira. O livre-arbítrio é um meio para realizar a liberdade, e um meio ambíguo. Bem empregado, liberta; malempregado, escraviza. O homem que abusa do álcool ou do sexo usa mal do seu livre-arbítrio e perde a sua liberdade, porque cai sob a tirania do vício. Por isso, o individualismo crê desempenhar-se de sua obrigação para com a sociedade, quando proclama uma liberdade puramente teórica, jurídica. Não se sente obrigado a colaborar concretamente para dar a todos os homens as possibilidades reais de ser homens, isto é, de ser livres.
\end{abstract}

Já no que diz respeito aos valores democráticos em relação a igualdade, importante mencionar sobre a igualdade com fundamento do art. $5^{\circ}$ da Constituição Federal, independentemente de credo, etnia, sexo, condição social, em consonância com o princípio da isonomia, que trata da igualdade, no sentido de tratar os desiguais, na medida de suas desigualdades. Referida igualdade, merece uma preocupação não somente nos direitos políticos, e agir em sociedade, mas também nos direitos sociais, em relação os contratos de trabalho, nos termos da Convenção de nº 158 da OIT $^{22}$.

Por fim, em relação ao valor democrático da solidariedade, cumpre observar que se trata de um conceito voltado à proteção da pessoa humana e da comunidade humana, sem qualquer distinção, a partir de uma ajuda mútua, sem levar em consideração qual pessoa humana. Desta forma, pode elencar a solidariedade não só como um valor democrático, mas um movimento, conforme ensina ÁVILA (1997, p.155-157):

Como doutrina, o Solidarismo tem como categorias básicas a pessoa humana e a comunidade humana. A pessoa, como ser racional, livre, social é portadora de uma vocação a um destino transcendente ao mero processo

\footnotetext{
${ }^{22} \mathrm{~A}$ proposta de negociação nos termos da Convenção 158 da OIT, baseada na liberdade sob a ótica do Capitalismo Humanista volta-se para o desenvolvimento integral do ser humano, a proteger o trabalhador a própria sociedade dos efeitos decorrestes da despedida em massa. [...] Não se busca com isso sacrificar o empregado em detrimento de ilimitados direitos conferidos ao trabalhador. [...] Pelo contrário, utilizando-se da ótica quântica, que considera indissociáveis empregador em empregado, e não a sua posição antagônica, propõese a união de intuitos, através da negociação coletiva, para que tais partes, indissociáveis e igualmente importantes para o processo econômico e produtivo, alcancem soluções praticáveis para o enfrentamento dos momentos de crise. [...] Tal proteção, entretanto, necessita conceder ao empregador o mesmo respeito rendido ao empregado, eis que tais partes não se sobrepõem, não são antagônicas, mas indissociáveis e imprescindíveis para a economia. (DUARTE, Juliana F. A. PELLINI JUNIOR, Roberto. Crise Econômica, Demissões em Massa, Direitos Fundamentais e o Capitalismo Humanista. In Estudos do Capitalismo Humanista Rio: Lumen Juris, 2017, p.182-183).
} 
histórico em que está envolvida e do qual participa como agente consciente. [...] A pessoa humana tem direitos naturais à vida digna, à educação, ao trabalho, à liberdade, à propriedade. $\mathrm{O}$ Solidarismo entende estes direitos não como meras outorgas legais, mas como possibilidades concretas. [...] $\mathrm{O}$ solidarismo sabe que as estruturas sociais vigentes não oferecem possibilidades reais para a realização destes direitos. [...] O Solidarismo não se constitui de negações, de anátemas. Sua essência não é ser anticapitalista ou anticomunista. Tem uma consistência própria, uma mensagem própria de sua dinâmica e esta é capaz de transformá-lo em movimento. Existem múltiplas forças solidaristas em marcha. Muitos movimentos que se encaminham obscuramente para um ideal solidarista. É tarefa do solidarismo, não tanto criar um movimento novo, quanto enfeixar, dar conteúdo e objetivo às forças solidaristas atuantes que se desconhecem.

A possibilidade de "agir", defendido no próximo item, por Hannah Arendt, só pode ser concretizada, juntamente com valores democráticos, tais como liberdade, igualdade e, principalmente, solidariedade. Aqui não devemos confundir este último valor com a fraternidade, pois ser fraterno envolve laços afetivos com pessoas próximos, afeto de irmandade. Ser solidário é ajudar de forma mútua, e até mesmo ser agente passivo desta ajuda, mesmo que não tenha nenhuma relação de afeto com a pessoa que necessita. É desta forma que deve ser em relação aos direitos políticos.

Diante do exposto, verifica-se que os direitos humanos impactaram diretamente nos direitos políticos, principalmente após a final da Segunda Guerra Mundial, diante não só a Declaração Universal dos Direitos Humanos, mas com os Pactos Internacionais de 1966, proporcionando maior participação política - principalmente para os países Ocidentais adeptos dos referidos diplomas internacionais - enaltecendo os valores democráticos, vale dizer, a liberdade, igualdade e solidariedade.

\section{IMPACTOS POSITIVOS DA GLOBALIZAÇÃO NOS DIREITOS POLÍTICOS}

A globalização tem uma ênfase maior após a segunda guerra mundial, principalmente diante a união de todos os povos em busca de um desenvolvimento em comum. O filósofo polonês BAUMAN (1999), na obra "Globalização: as consequências humanas", discorre desde a introdução, deixando como essência de sua obra que a globalização para alguns é a busca para felicidade, e para outros é o motivo da própria infelicidade, entretanto não tem como reverter este processo contínuo da humanidade, que influencia a todos, tornando o Mundo Global como regra.

Isto porque, também é motivo para a riqueza de uma minoria e segregação de outros, que não conseguem seguir as regras ditadas pelo regime capitalista, que de um lado conecta a 
todos em um único sistema econômico, por outro, distancia aquelas pessoas com menos oportunidades de concorrer com as demais.

Ao relacionar a globalização com o direito humano, faz-se necessária uma reflexão que para sua concretização é preciso união e não segregação; é preciso que todos realmente sejam felizes e não infelizes; e principalmente a concretização das atividades fundamentais como labor, trabalho e ação, segundo ensina a filósofa alemã HANNAH ARENDT, em "A Condição Humana" (2016, p. 345-347). Vejamos:

(...) atividades fundamentais que integram a vita activa: labor, trabalho e ação. (...) A ação, diz Hannah Arendt, é a única atividade que se exerce diretamente entre os homens sem a mediação das coisas ou da matéria. Corresponde à condição humana de pluralidade, ao fato de que homens, e não o Homem, vivem na Terra e habitam o mundo. Todos os aspectos da condição humana têm alguma relação com a política; mas esta pluralidade é especificamente a condição... de toda vida política. (...). O isolamento destrói a capacidade política, a faculdade de agir. É aquele impasse no qual os homens se veem quando a esfera política de suas vidas, onde agem em conjunto na realização de um interesse comum, é destruído. O isolamento que é a base de toda tirania, não atinge, no entanto, a esfera privada.

Neste diapasão, é de se concluir ser impossível existirmos isoladamente, sendo que para efetivamente ter a concretização dos direitos políticos no mundo globalizado, são necessários mecanismos integradores relacionados a ação do indivíduo em sociedade de forma conjunta ${ }^{23}$.

Este caminhar de concretização dos direitos políticos deve estar relacionado com um bom governo, e que estes governantes tenham a consciência de que é preciso uma gestão positiva e humana. Esta problemática, vem desde as grandes Revoluções - Americana e Francesa - em buscar não só do rompimento com a Coroa, e sim, o "direito a ter direitos", pautado na liberdade política "uma vez que o governo é para o indivíduo e não o indivíduo para o governo, pois a pessoa humana tem uma dignidade e uma especificidade que não se dissolve no todo da boa gestão da comunidade política"24.

\footnotetext{
${ }^{23}$ Ora, politicamente não existimos isolados, mas coexistimos. Daí a tensão entre a filosofia - na qual o pensar é a dualidade do dialogo coerente do eu consigo mesmo - e a política, na qual a pluralidade exige um estar sempre ligado aos outros, pois se podemos pensar por conta própria, só podemos agir em conjunto (ARENDT, 2016, p. 348).

${ }^{24} \mathrm{Na}$ análise política é útil distinguir a perspectiva dos que governam e exercem o poder, da perspectiva dos governados. Na história das ideias políticas, no trato destas duas perspectivas, sempre houve, a começar pelos gregos, uma preocupação com a promoção do bom governo, ou seja, com a sabedoria dos governantes necessária para uma gestão positiva em prol dos governados. A temática dos direitos humanos, no entanto, tal como introduzida pela Revolução Americana e pela Revolução Francesa, foi muito além da preocupação com o bom governo. Representou uma mudança radical na relação governantes/governados ao afirmar a passagem dos deveres dos súditos para os direitos da cidadania. Inaugurou-se dessa maneira, a legitimação plena da perspectiva
} 
Em conseguinte, necessário que esta liberdade política, advinda de uma boa gestão, em busca da coletividade, tenha base em uma política democrática, em que haja o respeito mútuo entre governantes e governados, com a positivação de direitos garantistas ao bem-estar $\operatorname{social}^{25}$.

Os direitos voltados ao bem-estar social estão previstos no artigo $5^{\circ}$ da Constituição Federal de 1988, também conhecidos como direitos fundamentais. Em que pese deveriam ser plenamente efetivos, muitas ações são necessárias para a concretização desses direitos, frequentemente necessitando da ajuda do setor produtivo.

Tanto o direito à liberdade e o direito social, tem relação direta a chamada de primeira dimensão e segunda dimensão de direitos, respectivamente, sendo que uma complementa a outra para que o indivíduo possa exercer seus direitos de cidadania ${ }^{26}$.

Muito embora sejam procedentes diversas críticas levantadas ao fenômeno da globalização, nos moldes em que vem sendo implementado nas últimas décadas, é evidente que esse fenômeno engendrou impactos positivos na efetivação dos direitos humanos, tanto os

dos governados, pois estes começam a ter, como diria Hannah Arendt, o "direito a ter direitos". (...) O "direito a ter direitos" é o que distingue a República dos Modernos da dos Antigos. Com efeito, para os antigos, a defesa da liberdade dos governados e a contenção da tirania como parte dos ingredientes do bem governo, era algo a ser obtido por meio do contrapeso dos poderes dos governantes, através do governo misto, tal como teorizado por Políbio - matriz inspiradora da divisão dos poderes. Já para os modernos, como aponta Bobbio, legitimação plena da perspectiva ex parte Populi veio a significar que a qualidade da convivência coletiva requer os direitos humanos, uma vez que o governo é para o indivíduo e não o indivíduo para o governo, pois a pessoa humana tem uma dignidade e uma especificidade que não se dissolve no todo da boa gestão da comunidade política (LAFER, 1995, p. 201).

${ }^{25}$ A passagem do dever dos súditos para o direito dos cidadãos é fundamental para a compreensão da democracia encarada na perspectiva da relação governantes/governados. De fato, numa democracia, as "regras do jogo" pressupõe a distribuição do poder entre os governados - o princípio da maioria, em consonância com a fórmula de Bobbio, é melhor "contar cabeças do que cortar cabeças" - e a limitação do poder dos governantes em obediência ao dever que têm de respeitar os direitos dos governados, vistos como cidadãos e não como súditos. No plano interno dos Estados, a construção política da democracia, com base no "direito a ter direitos", tem uma evolução conhecida que me permito sumariar. Primeiro, com base numa nítida demarcação Estado/sociedade, foram afirmados e positivados os direitos de garantia de cunho individualista como, por exemplo, a liberdade de expressão e de pensamento que corroeram o monopólio do poder ideológico dos governantes. A eles se agregaram os direitos individuais exercidos coletivamente, como a liberdade de associação, base do pluralismo democrático, daí advindo, na prática política, a formação dos partidos, dos sindicatos operários e o direito de grave. Esses direitos, chamados de primeira geração, são o fruto de uma herança liberal, e tiveram um papel decisivo na construção da democracia e na extensão da cidadania. (...) E estes sucederam os assim chamados direitos de segunda geração que provêm da herança socialista. São os direitos que contemplam uma participação, um crédito do indivíduo em relação ao todo, ou seja, ao "bem estar social", concebidos como bens que os homens, através de um processo coletivo, vão acumulando no tempo. É o caso do direito ao trabalho, á saúde, à educação.

${ }^{26} \mathrm{Na}$ perspectiva ex parte Populi os direitos de primeira geração (os direios civil e políticos) e os direitos de segunda geração (os direitos socioeconômicos e culturais) complementam-se, pois titular do direito é sempre o indivíduo e os direitos de segunda geração buscam dar meios para o pleno exercício dos direitos de primeira geração, através da extensão erga omnes das condições de exercício da cidadania. Os direitos de primeira geração e os de segunda geração, na sua evolução histórica conceitual, conjugaram-se na experiência francesa e norte-americana, no plano interno, com base num direito de titularidade coletiva: o da autoderteminação nacional da soberania popular. É por isso que, durante longo período, imaginou-se que os direitos do homem e os direitos dos povos caminhavam juntos (idem, p. 203). 
de primeira quanto os de segunda geração. Por exemplo, a globalização fortaleceu os valores democráticos, que passaram a ser aceitos em um número cada vez maior de países. Além disso, a crescente participação das mulheres no mercado de trabalho e na vida política se consolidou com o aumento do fluxo de pessoas, mercadorias e informações.

Em relação aos direitos humanos políticos, necessário também a concretização não só dos direitos de primeira geração, mas também de um governo democrático, que possam efetivar garantias, já positivadas no artigo $5^{\circ}$ da nossa Carta Magna vigente.

É fato, que o Brasil já passou por períodos - como da ditadura - em que os direitos humanos políticos foram visivelmente feridos, entretanto não podemos deixar de lado, que para que a influência da globalização no direito humano político seja pautada como uma condição humana é preciso concretizar as palavras de Hannah Arendt, conforme acima exposto, no sentido de permitir um labor, trabalho e ação na vida humana, em relação a esta última, principalmente em relação aos direitos políticos.

Nesta linha de análise, pontua-se que a globalização tem contribuição positiva com os direitos políticos, pois diante da união do globo, ou a denominada Aldeia Global, conforme estudo no primeiro item, à luz de IANNI, levou incorporação dos tratados de direitos humanos - principalmente os Pacto de 1966 que trata dos Direitos Civis - ampliando a participação seja de forma ativa ou passiva, da pessoa humana, nas relações políticas.

\section{O AVANÇO DA GLOBALIZAÇÃO E A ATUAL CRISE DA REPRESENTAÇÃO POLÍTICA.}

O avanço da globalização, conforme analisamos, trouce uma integração global, com ênfase nos países Ocidentais, principalmente após a Segunda Guerra Mundial, diante o número consideráveis de acontecimentos históricos, tais como a Declaração Universal dos Direitos Humanos, o Pactos Internacionais de 1966, a Guerra Fria, a queda do muro de Berlim, e principalmente, pelo aumento as informações mundiais, por intermédio da internet.

Nesse sentido, verifica-se uma possibilidade de maior participação política do indivíduo jamais visto, se analisarmos toda a construção histórica, desde do conceito de política à luz de Aristóteles, até a forma ativa, com necessidade de agir, labor e trabalho, como condição humana para um direito político, conforme defendido por Hannah Arendt.

Contudo, a marcha da globalização, ao mesmo tempo que trouxe inúmeros pontos favoráveis, inclusive em relação aos direitos humanos, por exemplo, na concretização de 
valores democráticos, como a liberdade, igualdade e solidariedade, também trouxe aspectos negativos que devem ser levados em consideração. É inequívoca a relação entre globalização econômica, sociedade de consumo e a degradação ambiental em escala planetária, marcada sobretudo pela redução da diversidade biológica, desertificação e mudanças globais do clima. Atualmente, há uma inequívoca "crise da representação política", que é claramente perceptível, tanto em âmbito internacional como em nosso país.

Assim, devemos enfatizar se realmente o agir, labor e trabalho, como condição humana para um direito político e os valores democráticos, estão sendo respeitados. Isto porque, atualmente está sendo colocada em "xeque" a legitimidade dos partidos políticos, diante da não representatividade das pessoas que deveriam representar.

Sem contar que, diante a corrupção em massa que todos os dias temos o dissabor de acompanhar pelos noticiários, até que ponto representa a verdade ou se não estamos diante de uma manobra de manipulação política, que ganha uma força ainda maior quando envolvem as chamadas fake news.

Todo este cenário acaba gerando uma desmotivação do cidadão em agir perante seus direitos, diante a desestímulo pelos partidos que acreditava estar representado, trazendo uma crise na democracia.

Este cenário, não é somente no Brasil, pois a internet, que tanto influencia para unir a chamada "Aldeia Global”, também retrata notícias em inúmeros países do globo, como por exemplo, a proliferação de fake news na atual "Era Trump". Na Europa, por sua vez, o desencanto com a política resulta da sensação de que as decisões macroeconômicas são tomadas longe dos cidadãos, em Bruxelas, pelo Banco Central Europeu (BCE), Comissão Europeia e Cúpulas da Zona do Euro, conforme relatam HENNETTE, PIKETTY, SACRISTE e VAUCHEZ em "Por uma Europa Democrática"27.

Todos os escândalos políticos envolvendo desvios de verbas públicas e pagamentos de propina, acabam por gerar uma crise na representação política, que deveria ser pautada em uma ação voltada à proteção da dignidade. Nesse contexto, atualmente muitos eleitores já não confiam no partido que aparentemente estava relacionado com seus ideais.

Outra influência da globalização, que não é positiva, sendo uma tendência no mundo da globalização, em relação direta no direito político, está voltada as chamadas fake news, ou seja, boatos virtuais com uma velocidade de disseminação imensurável, por intermédio da

\footnotetext{
${ }^{27}$ HENNETTE. Stéphanie; PIKETTY, Thomas; SACRISTE, Guillaume; VAUCHEZ, Antonie. Por uma Europa democrática. Rio de Janeiro: Editora Intrínseca, 2017.
} 
pessoa humana, que vale-se dos meios de comunicação, sendo necessário um grupo árduo de trabalho por meio dos órgãos públicos, na tentativa de coibir e sancionar os responsáveis ${ }^{28}$.

A busca pela concretização da democracia aumentou principalmente após a metade do século XX, em decorrência dos direitos políticos, conforme já analisamos, entretanto, por influência da própria globalização que proporcionou este avanço, hoje um dos seus mecanismos - internet, através das redes sociais - está levando há certo declínio e descrédito em relação ao agir e trabalhar de forma política, para uma condição humana.

Todo este cenário político, acaba descontruindo todo o avanço nos direitos políticos, sendo necessária uma reflexão diante destas novas experiências e tendências, para a continuidade da efetivação dos direitos políticos, como condição humana, evitando uma afronta aos valores democráticos: liberdade, igualdade e solidariedade.

A globalização trouxe significativas influências positivas, contudo, após a virada do século, é de se elencar inúmeros aspectos desfavoráveis, não só nos direitos humanos políticos, mas também em relação coisificação humana, devendo haver uma reflexão em relação aos valores democráticos, principalmente em relação à solidariedade ${ }^{29}$.

\footnotetext{
${ }^{28}$ As fake News se espalham mais rápido e atingem mais pessoas na redes sociais que as notícias verdadeiras, revela um estudo publicado em março deste ano, na revista científica Science. A velocidade é maior quando se trata de uma notícia de termos político, mesmo sendo mentirosa. Realizada por pesquisadores do Massachusetts Institute of Tecnology (MIT), dos Estados Unidos, o trabalho surpreendeu ao apontar o principal responsável pela disseminação das fake News. Não é culpa dos robôs (softwares programados para enviar, curtir e compartilhar posts nas redes sociais) nem do social media cyborgs, grupos que deliberadamente criam milharesm de constas em redes sociais e passam a propagar opiniões sobre diversos temais sem base factual. O culpado é a pessoa, o usuário, o ser único disposto a fazer circular em um grupo de familiares e amigos uma notícia que leu e não verificou a origem, que leu e não checou, que não leu (sequer conferiu o título) e, mesmo assim, curtiu e compartilhou. [...] Em entrevista colhida junto com sua assessoria, o Ministro Luiz Fux, do STF, [...] confirmou a criação da criação de um grupo de trabalho formado por membros do TSE, da Polícia Federal e da Procuradoria-Geral da República para coibir as fakes News e imputar sanções aos que desrespeitam as determinações da lei no que se refere à veiculação de notícias falsas, sejam elas produzidas por empresas ou pessoas físicas, tenham objetivos argentários ou políticos (GOMES, Marcus Vinícius. Fake News: a mentira Dissimulada. In: revista Boniuris, ano 30, edição nº52, jun/jul de 2018, p.24).

${ }^{29}$ Que o mundo é este no qual estamos vivendo, no qual a indiferença coisifica a pessoa do ser humano, sem se importar com seu valor, com sua essência, com seus sentimentos, e o pior, com a sua existência? O que se pode dizer a respeito das crianças desamparadas, muitas vezes drogadas, que vagam pelas ruas e dormem nas calçadas dos centros das grandes metrópoles? O que se pode dizer a respeito de um pai ou de uma mãe que, no auge da miséria humana, olham para os seus filhos chorarem porque passam fome e nada podem fazer para conter as lágrimas inocentes? O que se pode dizer das escolas sem livros, sem carteiras, sem merenda; dos postos de saúde sem médicos, sem remédios, sem atendimento; das longas filas de espera para o agendamento de uma cirurgia ou mesmo de uma consulta que, se acontece, já é tarde demais porque o indivíduo faleceu de dor ou exaustão? O que podemos dizer dos marginalizados relegados pela sociedade de instituições inacessíveis? (...) A civilização humana chegou num estágio em que seu elemento central perdeu o significado. Como diz Tércio Sampaio Ferraz Junior (2003, p. 259-261), o sentido primeiro da vida, que é a existência, expirou sua essência a partir da insignificância do homem para com o homem, na adoção do comportamento individual. Tal fato espanca de morte a própria razão da sociedade. (...) Sendo assim, é somente a partir do reconhecimento dos direitos do próximo que o ser humano poderá fazer da sociedade um ambiente propício à justiça e à segurança e, para tanto, o comportamento de solidariedade é o caminho mais adequado. (...) É aí que entra o Direito. Tendo por função social, além de outras, padronizar a conduta humana em favor da harmonia e da paz social o direito, na acepção de justo, deve atuar no sentido de transformar a realidade existente, não legitimando, pois, comportamentos
} 
Se não houver uma mudança e conscientização geral da população, à partir dos meios de comunicações e dos órgão públicos, para uma a retomada da importância dos valores democráticos e do agir na política, de forma ética, consciente e honesta, as experiências do passado para a construção de um direito humano político, para uma condição humana, acabará tendo com tendência toda esta construção que há séculos vem buscando.

Dentre todos os valores a ser resgatados, devemos dar ênfase na solidariedade ${ }^{30}$, para conduzir a novos horizontes, buscando a retomada de um direito humano político com justiça, sem indiferenças, retomando a credibilidade da crise de representatividade e, sobretudo, a responsabilidade dos governantes em termos de respeitar o princípio da dignidade da pessoa humana, principalmente das pessoas que ficam à margem da sociedade atual, fruto da globalização.

\section{CONCLUSÃO}

Todas as atrocidades praticadas durante a Segunda Guerra Mundial levaram os povos a uma reflexão a respeito da necessidade da união das Nações. Originou-se, assim, a Organização das Nações Unidas, em 1945. Logo depois, surge a Declaração Universal dos Direitos Humanos de 1948, e posteriormente os Pactos Internacionais de 1966, tanto os que tratam dos Direitos Civis e Políticos, como também os que tratam dos Direitos Econômicos, Sociais e Culturais, em que a proteção dos direitos políticos dos cidadãos é elevado à condição de piso mínimo da dignidade humana.

Para um entendimento maior do tema, o presente trabalho buscou tratar do conceito de política, partindo de um estudo em Aristóteles, em "Ética a Nicômaco", em que referida ciência tem ligação direta com a felicidade humana, uma vez que o modo de vida das pessoas e de como elas vivem em um determinado Estado, para que seja em harmonia, estes indivíduos devem ser felizes.

egoísticos, mirando sua atuação ao bem comum (CARDOSO, Alenilton da Silva. O Problema Social da indiferença no contexto ético da solidariedade. p. 122-123).

${ }^{30}$ A passagem das dimensões dos direitos ocorreu exatamente por essa "dinamogêsis" valorativa. A liberdade, que começou absoluta, posteriormente encontrou limites na igualdade e no fato de os homens almejarem uma vida justa em todos os aspectos. Com a chegada do novo direito, o fenômeno da eticidade impingiu à iniciativa privada contornos de justiça distributiva e social, não se admitindo mais a afirmação do "eu" como fundamento das atitudes tomadas. Afinal, essas mesmas atitudes geram efeitos difusos, e se é assim, a ética da solidariedade atribui aos particulares grande carga de responsabilidade. (...) o valor da solidariedade conduz o direito a uma prática de justiça, e aos poucos as instituições jurídicas vão se transformando para atender esse objetivo. Depois de ser totalitário, liberal/individualista, e agora solidário, o direito concentra suas forças para a formação de uma sociedade convergente aos seus fins, voltando-se, pois, a um estado ideal e de justiça (idem, p.123-124). 
Sendo assim, a política pode ser considerada a ciência da busca pelo bem-estar e felicidade a todos os homens de uma determinada sociedade em geral, entretanto, não podemos deixar de lado, que é uma difícil tarefa a ser cumprida pelos governantes, sendo que ser feliz é relativo para cada pessoa, diante os diferentes anseios humanos.

Sem esgotar o tema, também necessário relacionar a felicidade com o conceito de justiça e o princípio da igualdade. A partir de então, ampliou o objeto conceitual, para discorrer de forma breve sobre a ciência política, para o fim de demonstrar que o tema tem relação direta com várias áreas de estudo, desde o próprio Direito Constitucional, como Economia, Sociologia e História.

A partir de então, adentrou ao tema da construção do direito político, numa análise global, em breve síntese, principalmente após o final da segunda guerra mundial, assim como sua positivação na comunidade internacional.

Posteriormente, teve a preocupação de explicar o intuito dos direitos políticos, tanto de sua participação ativa como passiva, demonstrando ser um direito fundamental, que embora no Brasil sendo vítima de um retrocesso durante a ditadura militar, posteriormente foram conquistados e positivados na Carta Magna de 1988.

Todas as conquistas de ordem política realizadas após o fim da Segunda Grande Guerra, com o advento do fenômeno da globalização, a despeito dos aspectos negativos significativos, sendo considerado por alguns motivos de infelicidade e exclusão social, há inequívocos impactos positivos, incluindo a positivação de direitos políticos, em grande maioria dos países ocidentais, que hoje adotam o regime democrático.

Analisado sob este enfoque, os direitos humanos políticos, diante a influência da globalização, tem a concretização de uma melhor condição humana, principalmente nas atividades fundamentais preconizada por Hannah Arendt, sendo: labor, trabalho e ação, sendo necessário ainda a conscientização dos governantes, para uma maior concretização, que seja atuação seja em prol da coletividade/sociedade e não para atender interesses próprios e individuais.

Entretanto, em que pese toda a construção de forma positivo, principalmente após a metade do século $\mathrm{XX}$, o que vemos atualmente é uma crise de representatividade em relação aos direitos humanos políticos, devendo haver uma maior reflexão sobre o tema, principalmente em relação aos resgates de valores democráticos, tais como a liberdade e igualdade, e principalmente de solidariedade, para proporcionar uma melhor condição humana no agir, labor e trabalho, em relação aos direitos humanos políticos. 


\section{REFERÊNCIAS BIBLIOGRÁFICAS}

AVILA, Pe. Fernando Bastos. Solidarismo. Alternativa para a Globalização. 2a Ed., Editora Santuário: Aparecida, SP, 1997.

ARENDT, Hannah. A condição humana. Rio de Janeiro: Forense Universitária, 2016

ARISTÓTELES. Política. Tradução da Gama Kury. Brasília: Editora Universidade de Brasília, 1985.

BAUMAN, Zygmunt. Globalização: as consequências humanas. Tradução de Marcus Penchel. Rio de Janeiro: Jorge Zahar Ed., 1999

BARBOSA, Estefânia Maria de Queiroz. Precedentes Judiciais e Segurança Jurídica Fundamentos e Possibilidades para a Jurisdição Constitucional Brasileira. São Paulo: Saraiva, 2014.

BONAVIDES, Paulo. Ciência Política. 10ª Ed. São Paulo: Editora Malheiros, 2000.

BRASIL. Decreto No 592, de 6 de julho de 1992 - Entra em vigor o Pacto Internacional sobre Direitos Civis e Políticos (de 1966) no Brasil. Disponível em: http://www.planalto.gov.br/ccivil_03/decreto/1990-1994/d0592.htm. Acesso em: 12 mar. 2018.

Decreto $\mathbf{N}^{\circ}$ 7.030, de 14 de dezembro de 2009 - Promulga a Convenção de Viena sobre o Direito dos Tratados, concluída em 23 de maio de 1969. Disponível em: http://www.planalto.gov.br/ccivil_03/_ato2007-2010/2009/decreto/d7030.htm. Acesso em: 13 mar. 2018.

Ministério dos Direitos Humanos. Comissão Especial sobre Mortos e Desaparecidos. Disponível em: http://www.mdh.gov.br/assuntos/mortos-e-desaparecidospoliticos/programas/comissao-especial-sobre-mortos-e-desaparecidos-politicos. Acesso em: 09 mar. 2018.

COMPARATO, Fábio Konder. A afirmação histórica dos direitos humanos. São Paulo: Saraiva, 2007.

DAVID, René. Os grandes Sistemas do Direito Contemporâneo. Tradução de Hermínio A. Carvalho. São Paulo: Martins Fontes, 2002.

DUARTE, Juliana e PELLINI Jr. Crise Econômica, Demissões em Massa, Direitos Fundamentais e o Capitalismo Humanista. In Estudos do Capitalismo Humanista Rio: Lumen Juris, 2017. Página 167 e seguintes.

FRANCO JUNIOR, Hilário. Feudalismo. 2ª ed. São Paulo: Editora Brasiliense, 1984.

GAMO, Raphaela. O que são Direitos Políticos e sua relação com os Direitos Humanos?. [S.1., S.n], [entre 1995 e 2018]. Disponível em: 
http://www.apersonalidadejuridica.com.br/2016/04/o-que-sao-direitos-politicos-e-sua-relacaocom-os-direitos-humanos.html. Acesso em: 09 mar. 2018.

GOMES, Marcus Vinícius. Fake News: a mentira dissimulada. In: revista Boniuris, ano 30, edição nº52, jnh/jul de 2018.

HENNETTE. Stéphanie; PIKETTY, Thomas; Sacriste, Guillaume; VAUCHEZ, Antonie. Por uma Europa democrática. Rio de Janeiro: Editora Intrínseca, 2017.

IANNI, Octavio. A sociedade global. Rio de Janeiro: Civilização Brasileira, 2008

Teorias da Globalização. Rio de Janeiro: Civilização Brasileira, 2001.

LAFER, Celso. DESAFIOS: Ética e Política. São Paulo: Siciliano, 1995.

LONGCHAMP, Albert. Globalização: o novo nome do desenvolvimento. In Globalização e fé. Bauru: EDUSC, 2000.

MACEDO, Fausto. Cidadania aprisionada: O Direito eleitoral na ditadura. [S.l., s.n], [entre 1995 e 2018]. Disponível em: http://politica.estadao.com.br/blogs/faustomacedo/cidadania-aprisionada-o-direito-eleitoral-na-ditadura/. Acesso em: 06 jun. 2018.

MARINONI, Luiz Guilherme. A Ética dos Precedentes. Justificativa do novo CPC. São Paulo: Editora Revista dos Tribunais, 2014.

SAYEG, Ricardo e BALERA, Wagner. Capitalismo Humanista. Petrópolis: KBR, 2011. SILVA CARDOSO, Alenilton. $O$ problema social da indiferença no contexto ético da solidariedade. In Capitalismo Humanista e Direitos Humanos. Florianópolis: Conceito, 2000 .

TOSI, Giuseppe. A fraternidade é uma categoria política?. In: BAGGIO, Antonio Maria (Org.). O Princípio Esquecido. Exigências, recursos e definições da fraternidade na política. São Paulo: Cidade Nova, 2009. 